Check for updates

Cite this: Chem. Sci., 2019, 10, 11078

๑ All publication charges for this article have been paid for by the Royal Society of Chemistry

Received 3rd September 2019

rsc.li/chemical-science
Accepted 16th October 2019

DOI: $10.1039 / \mathrm{c} 9 \mathrm{sc} 04441 \mathrm{~h}$

\section{Direct functionalization of white phosphorus with anionic dicarbenes and mesoionic carbenes: facile access to 1,2,3-triphosphol-2-ides $\uparrow$}

\author{
Dennis Rottschäfer, (D) Sebastian Blomeyer, (D) Beate Neumann, \\ Hans-Georg Stammler and Rajendra S. Ghadwal (D)*
}

\begin{abstract}
A series of unique $C_{2} P_{3}$-ring compounds [(ADC $\left.\left.{ }^{A r}\right) P_{3}\right]\left(A D C^{A r}=\operatorname{ArC}\{(\operatorname{DippN}) C\}_{2} ; \operatorname{Dipp}=2,6-i \operatorname{Pr}_{2} C_{6} \mathrm{H}_{3} ; A r=\right.$ $\mathrm{Ph} \mathrm{4a}, 3-\mathrm{MeC}_{6} \mathrm{H}_{4} 4 \mathrm{~b}, 4-\mathrm{MeC}_{6} \mathrm{H}_{4} 4 \mathrm{c}$, and 4- $\mathrm{Me}_{2} \mathrm{NC}_{6} \mathrm{H}_{4} 4 \mathrm{~d}$ ) are readily accessible in an almost quantitative yield by the direct functionalization of white phosphorus $\left(\mathrm{P}_{4}\right)$ with appropriate anionic dicarbenes

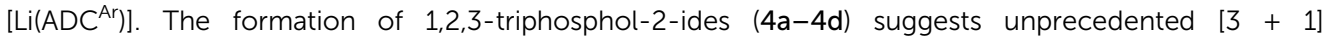
fragmentation of $\mathrm{P}_{4}$ into $\mathrm{P}_{3}{ }^{+}$and $\mathrm{P}^{-}$. The $\mathrm{P}_{3}{ }^{+}$cation is trapped by the (ADC $\left.{ }^{A r}\right)^{-}$to give 4 , while the putative $\mathrm{P}^{-}$anion reacts with additional $\mathrm{P}_{4}$ to yield the $\mathrm{Li}_{3} \mathrm{P}_{7}$ species, a useful reagent in the synthesis of organophosphorus compounds. Remarkably, the $\mathrm{P}_{4}$ fragmentation is also viable with the related mesoionic carbenes (iMICs ${ }^{\mathrm{Ar}}$ ) (iMIC ${ }^{\mathrm{Ar}}=\operatorname{ArC}\left\{(\mathrm{DippN})_{2} \mathrm{CCH}\right\}$, i stands for imidazole-based) giving rise to 4 . DFT calculations reveal that both the $\mathrm{C}_{3} \mathrm{~N}_{2}$ and $\mathrm{C}_{2} \mathrm{P}_{3}$-rings of 4 are $6 \pi$-electron aromatic systems. The natural bonding orbital (NBO) analyses indicate that compounds 4 are mesoionic species featuring a negatively polarized $\mathrm{C}_{2} \mathrm{P}_{3}$-ring. The $\mathrm{HOMO}-3$ of 4 is mainly the lone-pair at the central phosphorus atom that undergoes $\sigma$-bond formation with a variety of metal-electrophiles to yield complexes

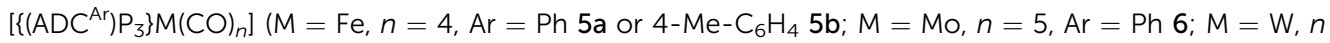
$\left.=5, \mathrm{Ar}=4-\mathrm{Me}_{2} \mathrm{NC}_{6} \mathrm{H}_{4} 7\right)$.
\end{abstract}

\section{Introduction}

The direct conversion of white phosphorus $\left(\mathrm{P}_{4}\right)$ into useful organophosphorus compounds (OPCs) is of significant interest because this excludes the involvement of corrosive $\mathrm{Cl}_{2}$ gas that is required to convert $\mathrm{P}_{4}$ into $\mathrm{PCl}_{3}$, a common starting material for OPCs, and thus minimizes the waste and energy consumption. ${ }^{1}$ The activation and subsequent functionalization of $\mathrm{P}_{4}$ has therefore become a topical objective. $^{2}$ Both transition metal $^{3}$ as well as main-group element $t^{4}$ compounds have been shown to activate or functionalize $\mathrm{P}_{4} \cdot{ }^{5}$ In particular, compounds featuring a lowvalent main-group element have made significant advances over the past years. ${ }^{6}$

Among nonmetals, the use of singlet carbenes ${ }^{7}$ has given new impetus to the field of $\mathrm{P}_{4}$ activation as it leads to the direct C-P bond formation (Fig. 1). ${ }^{8}$ Several stable carbenes (L1-L7) undergo reactions with $\mathrm{P}_{4}$ and the fate of $\mathrm{P}_{4}$ fragmentation to

Molecular Inorganic Chemistry and Catalysis, Inorganic and Structural Chemistry, Center for Molecular Materials, Faculty of Chemistry, Universität Bielefeld, Universitätsstr. 25, Bielefeld, D-33615, Germany. E-mail: rghadwal@uni-bielefeld. de; Web: https://www.ghadwalgroup.de

$\dagger$ Electronic supplementary information (ESI) available. CCDC 1939608-1939615. For ESI and crystallographic data in CIF or other electronic format see DOI: 10.1039/c9sc04441h give $\mathbf{P}_{n}(n=1,2,4,8$ or 12$)$ containing products II-IX depends on the relative $\sigma$-donor $/ \pi$-acceptor (ambiphilic) property as well as the steric demand of carbenes. ${ }^{7}$ Weakly $\pi$-accepting NHCs such as $\operatorname{IPr}\left(\mathrm{IPr}=\mathrm{C}\left\{(\right.\right.$ DippN $\left.) \mathrm{CH}_{\}_{2}}\right)$ do not react with $\mathrm{P}_{4}$, however, related derivatives containing the $\left[\mathrm{P}_{2}\right]$ or $\left[\mathrm{P}_{3}{ }^{-}\right]$moiety are accessible by alternative methods. ${ }^{9}$ Sterically demanding $1,3-$ $\operatorname{bis}(t \mathrm{Bu})$ imidazol-2-ylidene $\left(\mathrm{IBu}^{t}\right)$ activates $\mathrm{P}_{4}$ in combination with $\mathrm{B}\left(\mathrm{C}_{6} \mathrm{~F}_{5}\right)_{3}$ to give $\mathrm{X}^{6 h}$ This frustrated Lewis pair (FLP) type reactivity ${ }^{10}$ led to the transformation of the classical $\mathrm{NHC}\left(\mathrm{IBu}^{t}\right)$ into the mesoionic carbene (iMIC) L8 based on an 1,3-imidazole framework.

iMICs are very potent $\sigma$-donor ligands with almost negligible $\pi$-acceptor properties. ${ }^{11}$ Nonetheless, no reaction of an iMIC alone with $\mathrm{P}_{4}$ has been described so far. This is most likely due to their limited synthetic accessibility. ${ }^{11 a}$ We recently reported ${ }^{12}$ C5-protonated $\mathrm{iMICs}^{\mathrm{Ar}}$ (XI) as well as $\mathrm{C} 4 / \mathrm{C} 5$-ditopic anionic dicarbenes [ $\left.\mathrm{Li}\left(\mathrm{ADC}^{\mathrm{Ar}}\right)\right]$ XII (Fig. 1) by the deprotonation of C2arylated 1,3-imidazolium salts. ${ }^{13}$ The dicarbenes XII feature two adjacent C4/C5-nucleophilic sites, and thus are well endowed to affect unique dual $\mathrm{P}_{4}$ functionalization. ${ }^{5 i, 14}$ Herein, we showcase the direct functionalization of $\mathrm{P}_{4}$ via unprecedented $[3+1]$ fragmentation with $\left[\mathrm{Li}\left(\mathrm{ADC}^{\mathrm{Ar}}\right]\right.$ and $\mathrm{iMICs}^{\mathrm{Ar}}$ to give the 1,2,3-triphosphol-2-ide derivatives [( $\left.\left.\mathrm{ADC}^{\mathrm{Ar}}\right) \mathrm{P}_{3}\right]\left(\mathrm{ADC}^{\mathrm{Ar}}=\mathrm{ArC}\right.$ $\{\mathrm{NDipp}) \mathrm{C}\}_{2} ; \mathrm{Dipp}=2,6-\mathrm{iPr}_{2} \mathrm{C}_{6} \mathrm{H}_{3} ; \mathrm{Ar}=\mathrm{C}_{6} \mathrm{H}_{5} 4 \mathbf{4 a}, 3-\mathrm{MeC}_{6} \mathrm{H}_{4} 4 \mathbf{b}, 4$ $\mathrm{MeC}_{6} \mathrm{H}_{4} 4 \mathrm{c}$, and 4- $\mathrm{Me}_{2} \mathrm{NC}_{6} \mathrm{H}_{4} 4 \mathrm{~d}$ ) (Scheme 1). 


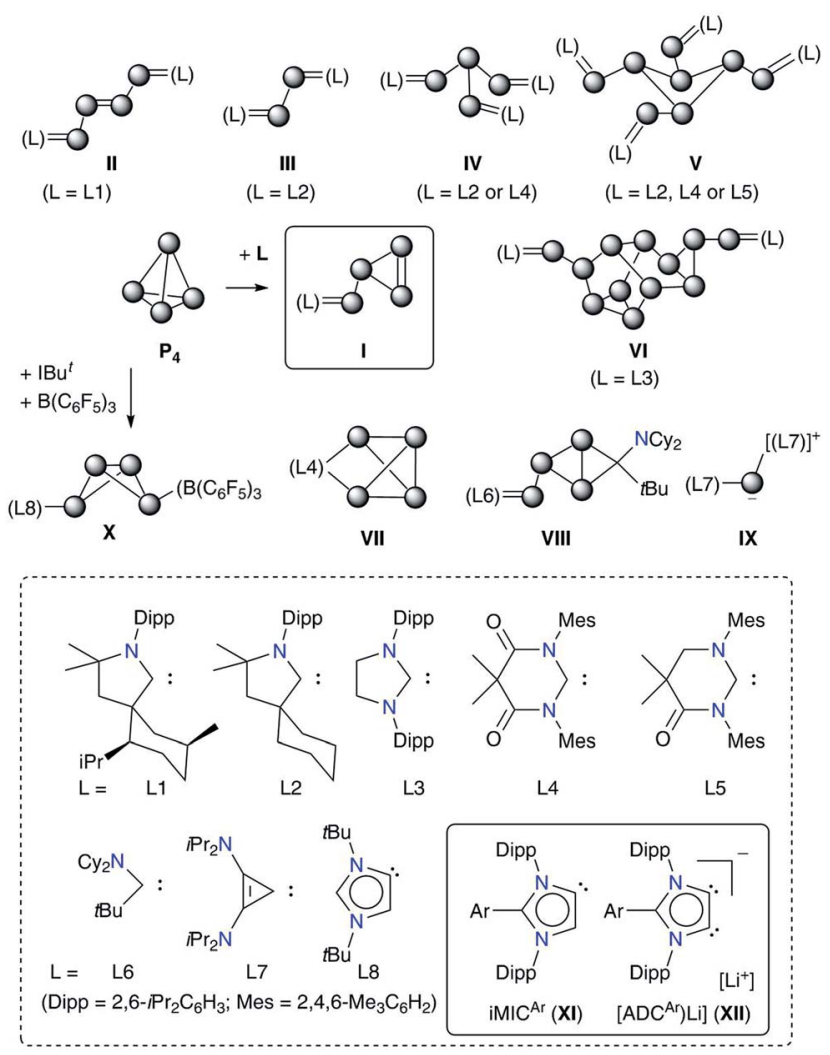

Fig. 1 Singlet carbene-mediated $\mathrm{P}_{4}$ activation and fragmentation to $\mathrm{II}-\mathrm{X}$ and a plausible intermediate I. Mesoionic carbenes (iMICs ${ }^{\mathrm{Ar}}, \mathrm{XI}$ ) and anionic dicarbenes (XII) $\left(\left[\mathrm{Li}^{+}\right]=\right.$solvated lithium ion) investigated in the current study.

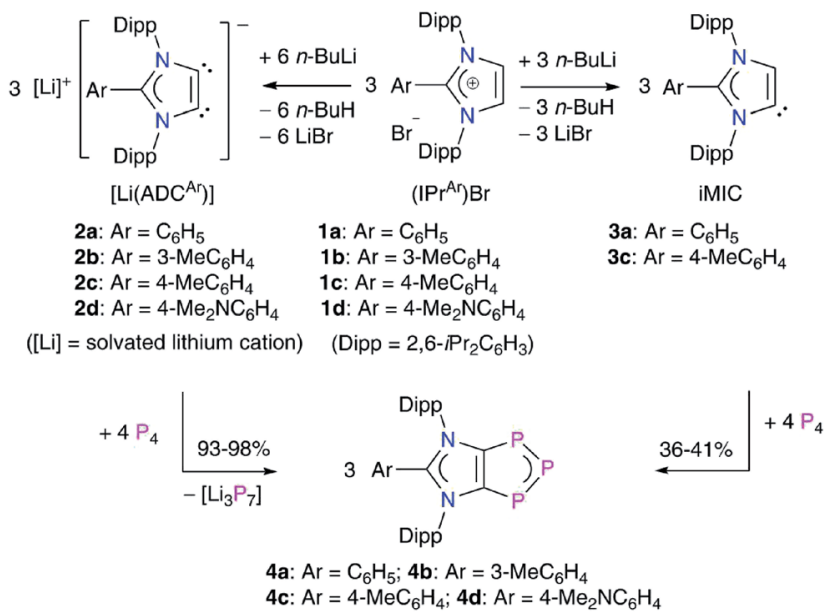

Scheme 1 Synthesis of 1,2,3-triphosphol-2-ide derivatives $4 a-4 d$ by the direct fragmentation of white phosphorus with [Li(ADC $\left.\left.{ }^{A r}\right)\right](2 a-2 d)$. Reaction of iMICs ${ }^{\mathrm{Ar}} 3 \mathrm{a}$ and $3 c$ with $\mathrm{P}_{4}$ to form $4 \mathrm{a}$ and $4 \mathrm{c}$.

\section{Results and discussion}

Treatment of $\left[\mathrm{Li}\left(\mathrm{ADC}^{\mathrm{Ar}}\right)\right](\mathbf{2 a - 2 d}){ }^{12}$ which are readily accessible by the double deprotonation of C2-arylated 1,3-imidazolium salts 1a-1d with $n$-BuLi, with $\mathrm{P}_{4}$ at room temperature afforded the 1,2,3-triphosphol-2-ides $\mathbf{4 a - 4 d}$ as crystalline solids in almost quantitative yields (Scheme 1). Compounds $\mathbf{4 a - 4 d}$ are indefinitely stable (as solids as well as in solutions) under an inert gas atmosphere. The formation of $\mathbf{4 a}-\mathbf{4 d}$ indicates formal $[3+1]$ fragmentation of $\mathrm{P}_{4}$ into $\mathrm{P}_{3}{ }^{+}$and $\mathrm{P}^{-}$. The cationic $\mathrm{P}_{3}{ }^{+}$ species is captured by the ADCs to give $\mathbf{4 a - 4 d}$, whereas the $\mathrm{P}^{-}$ nucleophile reacts with additional $\mathrm{P}_{4}$ to eventually form the phosphide $\left(\mathrm{P}_{7}\right)^{3-}$ anion, a very common species in metal mediated fragmentation of $\mathrm{P}_{4} \cdot{ }^{15}$ Indeed, $\mathrm{Li}_{3} \mathrm{P}_{7}$ can be isolated as a red-brown solid, ${ }^{15,16}$ which was confirmed by its reaction with (IPr) $\mathrm{HCl}$ to give (IPr)PH, reported previously using $\mathrm{Na}_{3} \mathrm{P}_{7} \cdot{ }^{17}$

Interestingly, treatment of iMICs ${ }^{\mathrm{Ar}} 3 \mathbf{a}$ and $3 \mathbf{c}$ with $\mathrm{P}_{4}$ also afforded, albeit in a lower yield, the corresponding products $\mathbf{4 a}$ and $\mathbf{4 c}$, respectively. ${ }^{1} \mathrm{H}$ NMR analyses of the crude reaction product indicate the presence of a $1: 1$ mixture of $4 \mathbf{a}: 1 \mathbf{a}$ and $4 \mathbf{c}: 1 \mathbf{c}$, suggesting the reprotonation of $\mathrm{iMICs}^{\mathrm{Ar}} 3 \mathbf{a}$ and $3 \mathbf{b}$ to $1,3-$ imidazolium salts 1a and 1c. Pure $\mathbf{4 a}$ and $\mathbf{4 c}$ can be extracted from the mixture using toluene.

The ${ }^{1} \mathrm{H}$ NMR spectra of $\mathbf{4 a}-\mathbf{4 d}$ are very symmetric and show two doublets and one septet for the isopropyl groups along with the signals due to the aryl protons. The ${ }^{13} \mathrm{C}\left\{{ }^{1} \mathrm{H}\right\}$ NMR resonances for $\mathbf{4 a - 4 d}$ are fully consistent with their ${ }^{1} \mathrm{H}$ NMR spectra. The ${ }^{13} \mathrm{C}\left\{{ }^{1} \mathrm{H}\right\}$ NMR spectrum of $\mathbf{4 a}-\mathbf{4 d}$ each exhibits a doublet at $167 \mathrm{ppm}\left(\mathrm{J}_{\mathrm{P}-\mathrm{C}} \approx 84 \mathrm{~Hz}\right)$ for the backbone carbon atoms due to coupling with the ${ }^{31} \mathrm{P}$ nucleus. The ${ }^{31} \mathrm{P}\left\{{ }^{1} \mathrm{H}\right\}$ NMR spectrum of 4a-4d each shows a doublet at $\sim 73 \mathrm{ppm}$ and a triplet at $325 \pm$ $6 \mathrm{ppm}$ in $2: 1$ ratio $\left(J_{\mathrm{P}-\mathrm{P}} \approx 500 \mathrm{~Hz}\right)$, indicating the presence of an $\mathrm{AB}_{2}$ type system with unsaturated $\mathrm{P}-\mathrm{P}$ bonds. ${ }^{18}$

Solid-state molecular structures $^{19}$ of $4 \mathbf{4 a}$ (Fig. 2), 4b (Fig. S47†), and $4 c$ (Fig. S48 $\dagger$ ) reveal the presence of a $\mathrm{C}_{2} \mathrm{P}_{3}$-ring that is coplanar with the imidazole $\mathrm{C}_{3} \mathrm{~N}_{2}$-ring plane. The metrical parameters of $\mathbf{4 a - 4 c}$ are comparable (Table $\mathrm{S} 1 \dagger$ ) and hence, for brevity, only $4 \mathrm{a}$ is discussed here. The P1-P2 bond length of $4 \mathbf{a}(2.103(1) \AA)$ is intermediate of the sum of covalent

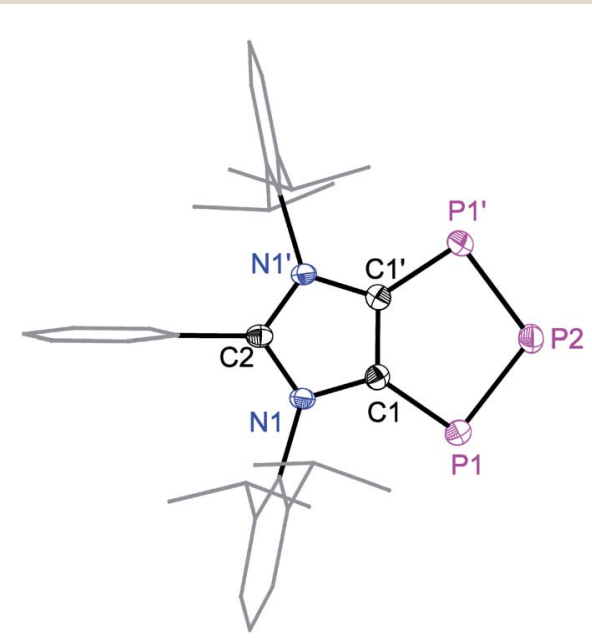

Fig. 2 Solid-state molecular structure of $4 a$. Hydrogen atoms are omitted for clarity. Symmetry code: $1-X,+Y, 3 / 2-Z$. Selected experimental and calculated [M06-2X/def2SVP] bond lengths $(\AA)$ and angles $\left({ }^{\circ}\right)$ : C1-C1' 1.395(5) [1.402], N1-C1 1.404(3) [1.399], P1-C1 1.757(3) [1.764], P1-P2 2.103(1) [2.112], C1-P1-P2 94.9(1) [94.8], and P1-P2-P1' 104.0(1) [104.1]. 


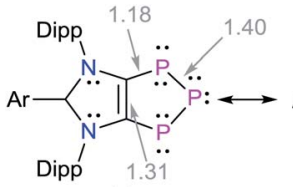

(a)

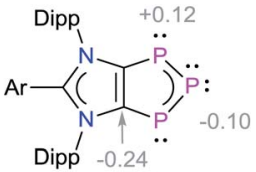

(b)

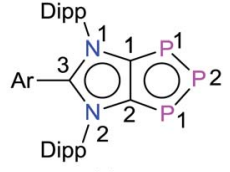

(c)
Scheme 2 (a) Calculated Wiberg Bond Indices (WBIs) and (b) NPA atomic charges of 1,2,3-triphosphol-1,2-ides 4 . (c) Schematic representation of 4 with atom numberings.

radii for $\mathrm{P}=\mathrm{P}$ double $(2.04 \AA)$ and $\mathrm{P}-\mathrm{P}$ single $(2.22 \AA)$ bond lengths ${ }^{20}$ indicating a partial $\pi$-bond character. Similarly, the C1-P1 (1.757(3) $\AA$ ) bond length of $\mathbf{4 a}$ is shorter compared to a classical C-P single bond length $(1.85 \AA)^{15}$ but compares well with $\mathrm{C}=\mathrm{P}$ bond lengths $(c a .1 .75 \AA$ ) of inversely polarized phosphaalkenes. ${ }^{17}$ The $\mathrm{C} 1-\mathrm{C} 1^{\prime}$ (1.395(5) $\AA$ ) and C2-N1 (1.404(3) $\AA$ ) bond lengths of $\mathbf{4 a}$ are elongated in comparison with those of 1a 1 1.350(2) and 1.344(2) A, respectively)..$^{13}$ The $\mathrm{C} 1-\mathrm{C} 1^{\prime}, \mathrm{C} 1 / \mathrm{C} 2-$ $\mathrm{P} 1$ and P1-P2 bond lengths of $\mathbf{4 a - 4 c}$ are comparable with the corresponding bond lengths of triphospholide anions $\left[\mathrm{P}_{3} \mathrm{C}_{2} \mathrm{R}_{2}\right]^{-}$ $(\mathrm{R}=\mathrm{H}, \mathrm{C}-\mathrm{P} 1.726(2)$ and 1.781(3), and P-P 2.081(1) and 2.094(1) $\AA ; \mathrm{R}=\mathrm{Ph}, \mathrm{C}-\mathrm{P}$ 1.760(2) and 1.762(2), and P-P 2.091(2), 2.098(2) A). ${ }^{21}$ Thus, $\mathbf{4 a}-\mathbf{4 d}$ may be considered as the neutral analogues of the triphospholide anions.

To gain further insight into the electronic structures of $4 a-$ 4d, we performed DFT calculations at the M06-2X/def2-TZVPP// M06-2X/def2-SVP level of theory. The computed NPA charges (Table S7 $\dagger$ ) at the $\mathrm{P} 2(-0.10 e)$ and the $\mathrm{C} 1 / \mathrm{C} 2(-0.24 e)$ atoms are negative, whereas both the $\mathrm{P} 1$ atoms bear a positive charge (0.12e) (Scheme 2). The Wiberg Bond Indices (WBIs) of 1.40 (P$\mathrm{P}), 1.18(\mathrm{C}-\mathrm{P})$, and $1.31(\mathrm{C}-\mathrm{C})$ indicate a partial double bond character. The WBI for the C1-C2 bond of $4 \mathrm{a}$ (1.31) is significantly smaller compared to that of the imidazolium salt 1a (WBI $=1.64)$. The WBIs for the C3-N1/2 bonds in 1 (1.28) and 4 (1.26) are, however, almost equal. Thus, compounds 4 may be described as mesoionic species with $6 \pi$-electron $\mathrm{C}_{2} \mathrm{P}_{3}$ and $\mathrm{C}_{3} \mathrm{~N}_{2}$ aromatic systems (Scheme 2c). The nitrogen atoms contribute $4 \pi$-electrons to the $\mathrm{C}_{3} \mathrm{~N}_{3}$-ring, whereas the $\mathrm{P}_{3}$ unit shares $4 \pi$ electrons with the $\mathrm{C}_{2} \mathrm{P}_{3}$-ring. The $2 \pi$-electrons of the $\mathrm{C} 1=\mathrm{C} 2$ bond are pooled by both the ring systems. Indeed, calculated nucleus-independent chemical shift (NICS) ${ }^{22}$ values for $\mathbf{4 a - 4 d}$ (Table 1) suggest the aromaticity of the $\mathrm{C}_{3} \mathrm{~N}_{2}-$ and $\mathrm{C}_{2} \mathrm{P}_{3}$-rings. For comparison, we also calculated the NICS values for $\mathrm{C}_{6} \mathrm{H}_{6}$ and cyclobutadiene (CBD) molecules.

The anisotropy of current-induced density (AICD) has been used to study the aromatic behavior of several molecules. ${ }^{23}$ The AICD plots of $\mathbf{4 a}$ (Fig. 3) and $\mathbf{4 b} \mathbf{b}-\mathbf{4 d}$ (Fig. S62 $\dagger$ ) clearly show

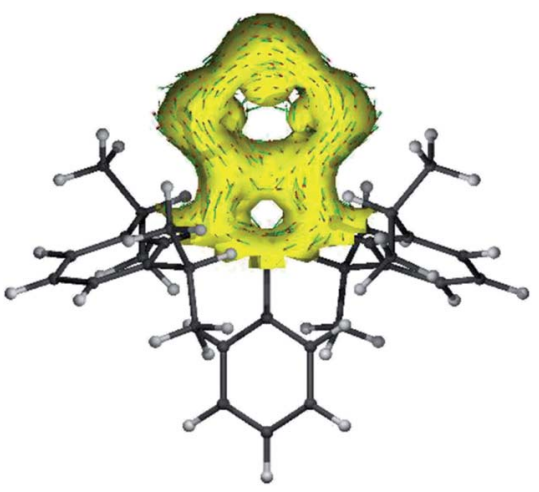

Fig. 3 AICD plot (based on M06-2X/def2-TZVPP//def2-SVP calculations) of the $\mathrm{C}_{3} \mathrm{~N}_{2} \mathrm{P}_{3}$ core of compound $4 \mathrm{a}$. The isovalue was arbitrarily chosen to be 0.03 , the magnetic field is orthogonal to the $\mathrm{C}_{2} \mathrm{P}_{3}$-plane and points towards the viewer, and thus clockwise ring currents represent aromatic systems, whereas counter-clockwise ring currents are indicative of antiaromatic systems. AICD plots of the complete molecules $4 a-4 d$ are given in the ESI. $\dagger$

significant delocalization of the $\pi$-electrons of both the $\mathrm{C}_{3} \mathrm{~N}_{2}$ and the $\mathrm{C}_{2} \mathrm{P}_{3}$ heterocycles, forming one coherent $\pi$-system.

The HOMO of compounds $\mathbf{4 a}$ (Fig. 4) and $\mathbf{4 b - 4 \mathbf { c }}$ (Fig. S58$\mathrm{S} 60 \dagger$ ) corresponds to the $\pi$-orbitals of the $\mathrm{C}-\mathrm{P}$ bonds with a small contribution from the lone pairs at the nitrogen atoms. The HOMO-1 corresponds mainly to the $\pi$-orbitals of the $\mathrm{P}_{3}$ and the $\mathrm{C}_{2}$ moieties of the $\mathrm{C}_{2} \mathrm{P}_{3}$-ring. Like in alkali metal 1,2,3triphospholides, ${ }^{21 b}$ the analyses of frontier molecular orbitals, HOMO and HOMO-1 in particular, of $\mathbf{4 a - 4 d}$ reveal the mixing of phosphorus orbitals with lone-pair character amongst the $\pi$ manifold frontier orbitals. The $\mathrm{HOMO}-3$ and $\mathrm{HOMO}-2$ are the lone pairs on the central and neighbouring $\mathrm{P}$ atoms, respectively. The LUMO of $\mathbf{4 a - 4 d}$ corresponds to the $\pi^{*}$ orbital of the aryl group on the $\mathrm{C} 3$ carbon atom along with a p-orbital at the central phosphorus atom. The LUMO+2 corresponds mainly to the $\pi^{*}$-orbitals of the $\mathrm{C}_{2} \mathrm{P}_{3}$ unit.

The intriguing electronic structures of 4 prompted us to investigate their ligand properties as they may function as neutral two electron $\sigma$-donors (via phosphorus atoms) and/or $6 \pi$-electron $\eta^{5}$-donors $\left(\mathrm{C}_{2} \mathrm{P}_{3}\right.$-ring) like triphospholide ${ }^{21}$ and cyclopentadienyl anions. Treatment of $4 \mathbf{a}, \mathbf{4 b}$, and $4 \mathbf{c}$ with $\mathrm{Fe}_{2}(\mathrm{CO})_{9}$ or $\mathrm{M}(\mathrm{CO})_{5}(\mathrm{THF})(\mathrm{M}=\mathrm{Mo}$ or $\mathrm{W})$ led to the formation of related complexes 5a, 5b, 6, and 7 (Scheme 3). In all complexes, the central phosphorus atom functions as a two-electron $\sigma$ donor ligand to bind to the $\mathrm{M}(\mathrm{CO})_{n}$ moiety. This is consistent with the NBO analysis, which suggests higher charge accumulation at the central phosphorus atom with respect to that of the

Table 1 Calculated NICS values for the $\mathrm{C}_{3} \mathrm{~N}_{2} / \mathrm{C}_{2} \mathrm{P}_{3}$ units of $4 a-4 d$ at the M06-2X/def2TZVPP//M06-2X/def2SVP level of theory

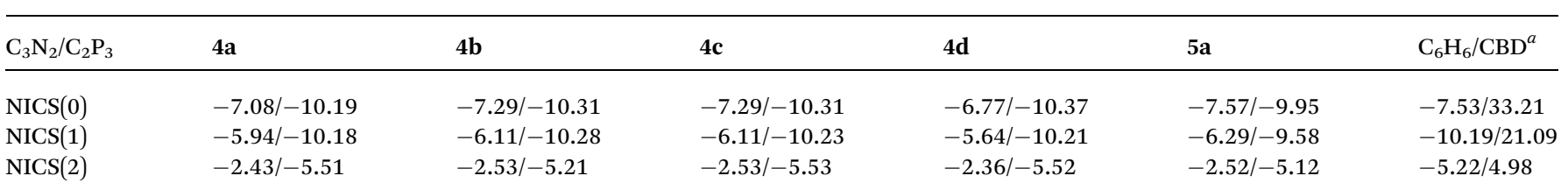

${ }^{a}$ CBD (cyclobutadiene). 

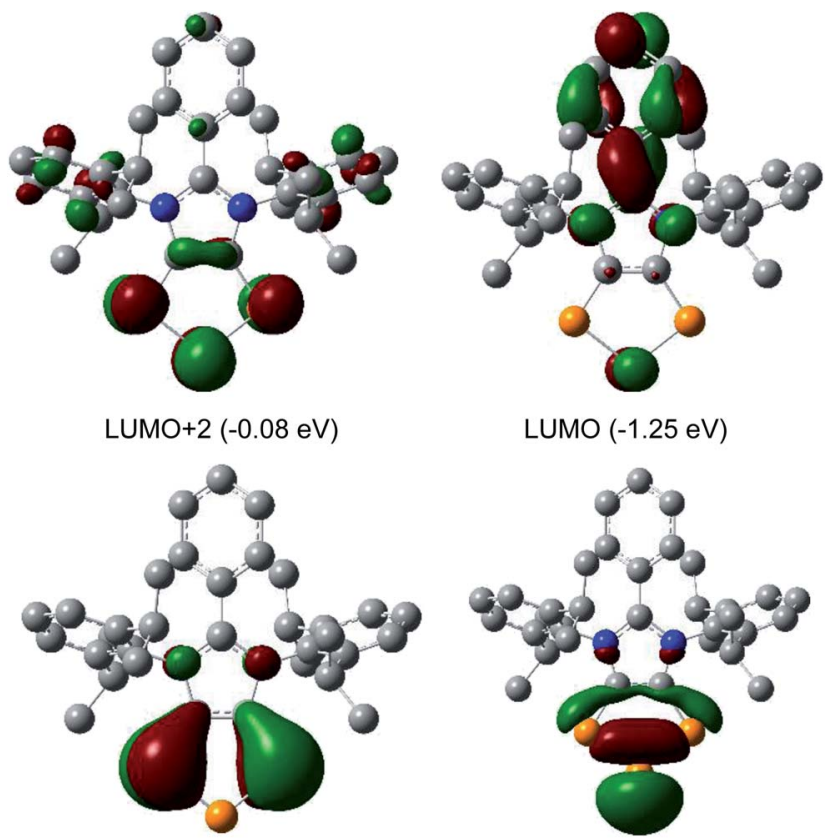

LUMO $(-1.25 \mathrm{eV})$

HOMO $(-6.08 \mathrm{eV})$

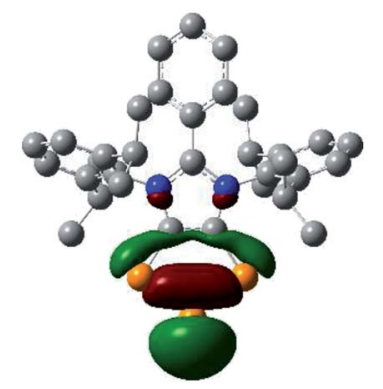

HOMO-3 (-7.50 eV)

Fig. 4 Selected MOs of $4 a$ calculated at the M06-2X/def2-TZVPP// def2-SVP level of theory with an isovalue of 0.04 . Hydrogen atoms were omitted for clarity.

neighbouring phosphorus atoms. The ${ }^{31} \mathrm{P}\left\{{ }^{1} \mathrm{H}\right\}$ NMR spectrum of $\mathbf{5 a}, \mathbf{5 b}, \mathbf{6}$, and 7 each exhibits one doublet $(\mathbf{5 a} \mathbf{a} 145 ; \mathbf{5 b}: 145 ; \mathbf{6}$ : 160; 7: $157 \mathrm{ppm}$ ) and one triplet (5a: 316; 5b: 315; 6: 299; 7: 250 ppm), which have been upfield shifted with respect to that of $4 \mathbf{a}$ (173, $332 \mathrm{ppm})$, 4b (173, $331 \mathrm{ppm})$, and $\mathbf{4 d}(173,319 \mathrm{ppm})$. In the ${ }^{31} \mathrm{P}\left\{{ }^{1} \mathrm{H}\right\}$ NMR spectrum of 7 , the triplet at $250 \mathrm{ppm}$ is accompanied by the ${ }^{183} \mathrm{~W}$ satellites $\left(\mathrm{J}_{\mathrm{P}-\mathrm{W}}=202 \mathrm{~Hz}\right)$.

The iron atom in $\mathbf{5 a}$ (Fig. 5) and $\mathbf{5 b}$ (Fig. S49†) each features a trigonal-bipyramidal geometry. Three equatorial positions are occupied by CO ligands, whereas one $\mathrm{CO}$ and one $4 \mathbf{a}$ or $\mathbf{4 b}$ are present at the axial positions. The P-Fe bond length of $\mathbf{5 a}$ $(2.240(1) \AA)$ compares well with that of triphosphaindanederived $\mathrm{P}_{3} \mathrm{Fe}_{3}$ iron-carbonyl clusters (av. $2.244 \AA$ ) ${ }^{24}$ Interestingly, the metrical parameters of the $\mathrm{C}_{3} \mathrm{~N}_{2}$ - and $\mathrm{C}_{2} \mathrm{P}_{3}$-rings of $5 \mathrm{a}$ and $\mathbf{5 b}$ are very similar to those of the precursors $4 \mathbf{a}$ and $\mathbf{4 b}$, respectively. This indicates that the aromatic $\pi$-systems remain virtually intact upon complexation of $\mathbf{4 a}$ and $\mathbf{4 b}$ with the $\mathrm{Fe}(\mathrm{CO})_{4}$ fragment. As expected, the molecular structures of 6 (Fig. S50†) and 7 (Fig. S51†) feature six-fold coordinated Mo and $\mathrm{W}$ atoms, respectively.
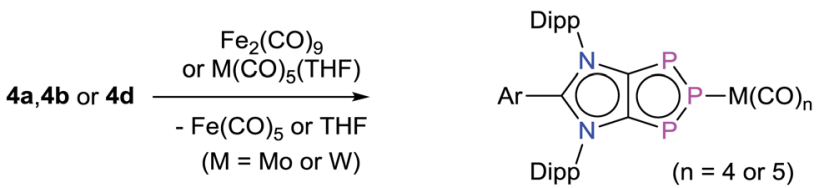

5a: $M=F e, A r=P h ; 5 b: M=F e, A r=3-M^{-} C_{6} H_{4}$ 6: $M=M o, A r=P h ; 7: M=W, A r=4-M_{2} N C_{6} H_{4}$

Scheme 3 Synthesis of complexes $\left[\left\{\left(A D C^{A r}\right) P_{3}\right\} M(C O)_{n}\right] 5 a, 5 b, 6$, and 7.

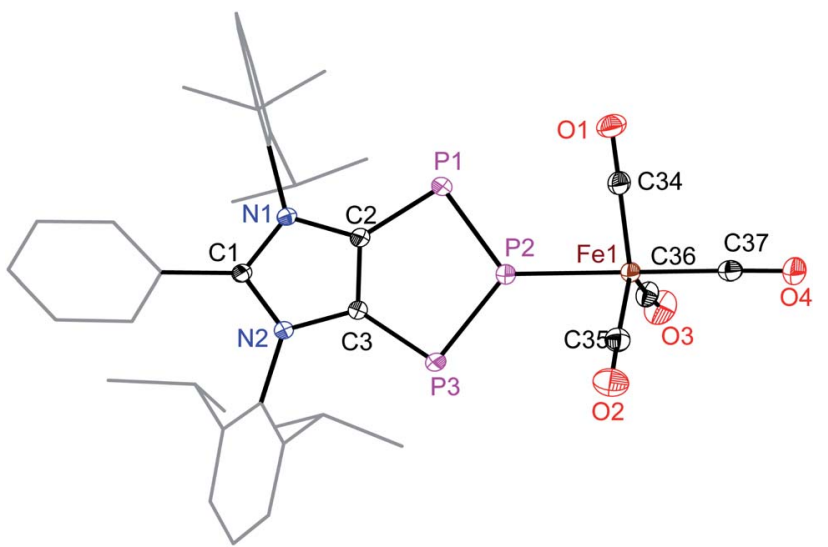

Fig. 5 Solid-state molecular structure of 5a. Hydrogen atoms and one solvent toluene molecule are omitted for clarity. Selected bond lengths $(\AA \AA)$ and angles $\left({ }^{\circ}\right)$ : C2-C3 1.394(2), C2-N1 1.399(1), C3-N2 1.403(1), C2-P1 1.756(1), C3-P3 1.764(1), P1-P2 2.081(1), P2-P3 2.089(1), P2-Fe1 2.240(1), Fe1-C34 1.791(1), Fe1-C35 1.797(2), Fe1C36 1.810(1), Fe1-C37 1.783(1), P1-P2-P3 109.1(2), and P2-Fe1-C37 178.5(1).

DFT calculations suggest that the HOMO of 5a (Fig. 6) is mainly located at the iron atom and has some contribution from the $\pi$-orbitals of the $\mathrm{C}-\mathrm{C}$ and one P-P bond. The LUMO is comparable to that of $\mathbf{4 a}$ but is lower in energy by $-0.26 \mathrm{eV}$, indicating metal-to-ligand $\pi$-back bonding. The aromaticity of the $\mathrm{C}_{2} \mathrm{P}_{3}$ moiety in 5a remains almost unchanged as indicated by $\operatorname{NICS}(0)=-9.95, \operatorname{NICS}(1)=-9.58$, and $\operatorname{NICS}(2)=-5.12$ values. The aromaticity of $\mathbf{5 a}$ is also corroborated by the AICD plot (Fig. S62†).

\section{Experimental}

All syntheses and manipulations were carried out under an inert gas atmosphere ( $\mathrm{Ar}$ or $\mathrm{N}_{2}$ ) using standard Schlenk techniques or a glove box (MBraun LABMasterPro). Solvents were dried over appropriate drying agents, distilled, and stored over a $3 \AA$ molecular sieve prior to use. Deuterated solvents were dried over appropriate drying agents, distilled, and stored inside a glove box. NMR spectra were recorded on a Bruker Avance III 500 or a Bruker Avance III 500 HD spectrometer. Chemical shifts (in $\delta, \mathrm{ppm}$ ) are referenced to the solvent residual signals of $\mathrm{CD}_{2} \mathrm{Cl}_{2}:{ }^{1} \mathrm{H} 5.32 ;{ }^{13} \mathrm{C} 53.84$ and $\mathrm{C}_{6} \mathrm{D}_{6}:{ }^{1} \mathrm{H} 7.16 ;{ }^{13} \mathrm{C} 128.62 \mathrm{ppm}$. ESI mass spectra were recorded using an Esquire 3000 ion trap mass spectrometer (Bruker Daltonik GmbH, Bremen, Germany) equipped with a nano-ESI source. Samples were dissolved in $\mathrm{CH}_{2} \mathrm{Cl}_{2}$ and introduced by static nano-ESI using in-house pulled glass emitters. Nitrogen served as a nebulizer gas as well as a dry gas and was generated by a Bruker nitrogen generator NGM 11 . Helium served as a cooling gas for the ion trap. The mass axis was externally calibrated with ESI-L Tuning Mix (Agilent Technologies, Santa Clara, CA, USA) as the calibration standard. UV/ vis spectra were recorded on a ThermoFisher Evolution 300 spectrophotometer. Infrared spectra were recorded using a Bruker Alpha-T FTIR spectrometer equipped with a Bruker Platinum diamond ATR unit. Melting points were measured 


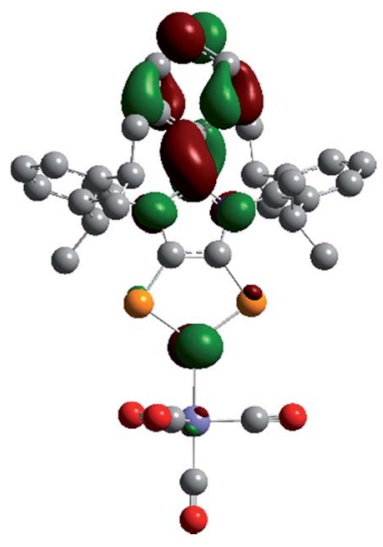

LUMO $(-1.51 \mathrm{eV})$

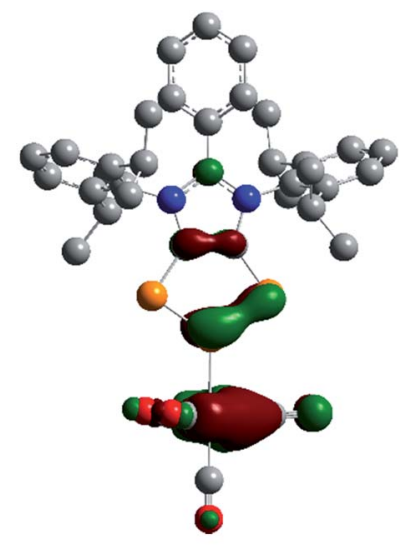

HOMO $(-6.42 \mathrm{eV})$
Fig. 6 Frontier molecular orbitals of 5 a calculated at the M06-2X/ def2-TZVPP//def2-SVP level of theory. The isovalue was arbitrarily chosen to be 0.04 . Hydrogen atoms were omitted for clarity.

with a Büchi B-545 melting point apparatus. ( $\left.\operatorname{IPr}^{\mathrm{Ar}}\right) \mathrm{Br}$ salts 1a1d $\left(\mathrm{Ar}=\mathrm{Ph}, 3-\mathrm{MeC}_{6} \mathrm{H}_{4}, 4-\mathrm{MeC}_{6} \mathrm{H}_{4}\right.$ or $\left.4-\mathrm{Me}_{2} \mathrm{NC}_{6} \mathrm{H}_{4}\right)$ were synthesized following the reported method. ${ }^{13 a} n$-BuLi $(2.5 \mathrm{M}$ solution in hexanes, Sigma-Aldrich) was used as received. White phosphorus was sublimed and stored inside a glovebox. Commercially available $\mathrm{Fe}_{2}(\mathrm{CO})_{9}$ (Sigma-Aldrich), $\mathrm{Mo}(\mathrm{CO})_{6}$ (Fluorochem), and $\mathrm{W}(\mathrm{CO})_{6}$ (Sigma-Aldrich) were used as supplied.

\section{Synthesis of compound $\left(\mathrm{ADC}^{\mathrm{Ph}}\right) \mathrm{P}_{3}$ (4a)}

To a $15 \mathrm{~mL}$ THF suspension of $1 \mathrm{a}(0.88 \mathrm{~g}, 1.6 \mathrm{mmol}), n$-BuLi (2.5 M, $1.4 \mathrm{~mL}, 3.5 \mathrm{mmol}$ ) was added at $-40{ }^{\circ} \mathrm{C}$. The resulting reaction mixture was stirred at $-20^{\circ} \mathrm{C}$ for $1 \mathrm{~h}$ and then at room temperature $\left(25^{\circ} \mathrm{C}\right)$ for 15 minutes to obtain a clear light brown solution of $2 \mathrm{a}^{12}$ To this solution, solid $\mathrm{P}_{4}(0.4 \mathrm{~g}, 3.2 \mathrm{mmol})$ was added in one portion and then stirred overnight at rt. The resulting dark suspension was refluxed for $2 \mathrm{~h}$ and the red insoluble material (probably a mixture of $\mathrm{Li}_{3} \mathrm{P}_{7}$ and other polyphosphides) was removed by filtration. The volatiles from the filtrate were removed under vacuum to give a brown residue, which was extracted with dichloromethane, dried under vacuum, washed with toluene $(2 \times 10 \mathrm{~mL})$, and re-dried to obtain compound $\mathbf{4 a}$ as a yellow solid. Yield: $96 \%(0.86 \mathrm{~g})$. Single crystals suitable for X-ray diffraction analysis were grown by storing a saturated toluene solution of $4 \mathbf{a}$ at $-24{ }^{\circ} \mathrm{C}$ for three days. Mp: $343{ }^{\circ} \mathrm{C}$. Elem. anal. (\%), calcd for $\mathrm{C}_{33} \mathrm{H}_{39} \mathrm{~N}_{2} \mathrm{P}_{3}$ (556.6): $\mathrm{C}, 71.21 ; \mathrm{H}, 7.06$; N, 5.03; found: $\mathrm{C}, 71.02 ; \mathrm{H}, 6.84 ; \mathrm{N}, 4.87 .{ }^{1} \mathrm{H}$ NMR (500 MHz, $\left.\mathrm{CD}_{2} \mathrm{Cl}_{2}, 298 \mathrm{~K}\right): \delta=7.59(\mathrm{t}, J=7.7 \mathrm{~Hz}, 2 \mathrm{H}, p$ $\left.\mathrm{C}_{6} H_{3}\right), 7.38\left(\mathrm{~d}, J=7.8 \mathrm{~Hz}, 4 \mathrm{H}, m-\mathrm{C}_{6} H_{3}\right), 7.34(\mathrm{t}, J=6.6 \mathrm{~Hz}, 1 \mathrm{H}, p$ $\left.\mathrm{C}_{6} H_{5}\right), 7.23-7.18\left(\mathrm{~m}, 4 \mathrm{H}, o-, m-\mathrm{C}_{6} H_{5}\right), 2.62$ (sept, $J=6.6 \mathrm{~Hz}, 4 \mathrm{H}$, $\left.\mathrm{CH}\left(\mathrm{CH}_{3}\right)_{2}\right), 1.26\left(\mathrm{~d}, J=6.6 \mathrm{~Hz}, 12 \mathrm{H}, \mathrm{CH}\left(\mathrm{CH}_{3}\right)_{2}\right)$, and $1.03(\mathrm{~d}, J=$ 6.7 Hz, $\left.12 \mathrm{H}, \mathrm{CH}\left(\mathrm{CH}_{3}\right)_{2}\right) \mathrm{ppm} .{ }^{13} \mathrm{C}\left\{{ }^{1} \mathrm{H}\right\} \mathrm{NMR}\left(126 \mathrm{MHz}, \mathrm{CD}_{2} \mathrm{Cl}_{2}\right.$, $298 \mathrm{~K}): \delta=167.6\left(\mathrm{~d}, J_{\mathrm{P}-\mathrm{C}}=84.4 \mathrm{~Hz}, C \mathrm{P}\right) ; 149.2(\mathrm{NCN}) ; 146.2$, 133.5, 132.0, 131.8, 129.8, 129.1, 125.8, and $123.8\left(C_{6} \mathrm{H}_{3}, C_{6} \mathrm{H}_{5}\right)$; $29.7\left(\mathrm{CH}\left(\mathrm{CH}_{3}\right)_{2}\right) ; 26.1$ and $23.5\left(\mathrm{CH}\left(\mathrm{CH}_{3}\right)_{2}\right)$ ppm. ${ }^{31} \mathrm{P}\left\{{ }^{1} \mathrm{H}\right\} \mathrm{NMR}$ $\left(202 \mathrm{MHz}, \mathrm{CD}_{2} \mathrm{Cl}_{2}, 298 \mathrm{~K}\right): \delta=332.3\left(\mathrm{t}, J_{\mathrm{P}-\mathrm{P}}=506 \mathrm{~Hz}\right)$ and 173.7 $\left(\mathrm{d}, J_{\mathrm{P}-\mathrm{P}}=506 \mathrm{~Hz}\right)$ ppm. MS (ESI, positive mode): $\mathrm{m} / z=557.3$ [4a
$+\mathrm{H}]^{+}$. UV-vis $\left(\lambda / \mathrm{nm} \varepsilon\left(\mathrm{M}^{-1} \mathrm{~cm}^{-1}\right)\right): 282$ (22336), 346 (31017), and 361 (31397).

Compounds $\mathbf{4 b - 4 d}$ were prepared by employing a similar protocol to that described for $4 \mathbf{a}$ using the appropriate precursor $1 \mathbf{b}, \mathbf{1 c}$ or $1 \mathrm{~d}, n-\mathrm{BuLi}$, and $\mathrm{P}_{4}$.

\section{$\left(\mathrm{ADC}^{3-\mathrm{Tol}}\right) \mathbf{P}_{3}(\mathbf{4 b})$}

Yield: $98 \%$ (0.90 g). Mp: $338-341{ }^{\circ} \mathrm{C}$. Elem. anal. (\%), calcd for 4b, $\mathrm{C}_{34} \mathrm{H}_{41} \mathrm{~N}_{2} \mathrm{P}_{3}$, (570.6): C, 71.56; $\mathrm{H}, 7.24 ; \mathrm{N} \mathrm{4.91;} \mathrm{found} \mathrm{C}$, 70.64; H, 7.33; N 4.68. ${ }^{1} \mathrm{H}$ NMR (500 MHz, $\left.\mathrm{CD}_{2} \mathrm{Cl}_{2}, 298 \mathrm{~K}\right): \delta=$ $7.57\left(\mathrm{t}, J=7.8 \mathrm{~Hz}, 2 \mathrm{H}, p-\mathrm{C}_{6} H_{3}\right), 7.35\left(\mathrm{~d}, J=7.8 \mathrm{~Hz}, 4 \mathrm{H}, m-\mathrm{C}_{6} \mathrm{H}_{3}\right)$, $7.14\left(\mathrm{~d}, J=7.6 \mathrm{~Hz}, 1 \mathrm{H}, o-\mathrm{C}_{6} H_{4}\right), 7.08\left(\mathrm{t}, J=7.8 \mathrm{~Hz}, 1 \mathrm{H}, m-\mathrm{C}_{6} H_{4}\right)$, $7.02\left(\mathrm{~s}, 1 \mathrm{H}, o-\mathrm{C}_{6} H_{4}\right), 6.96\left(\mathrm{~d}, J=7.8 \mathrm{~Hz}, 1 \mathrm{H}, p-\mathrm{C}_{6} H_{4}\right), 2.60$ (sept, $J$ $\left.=6.7 \mathrm{~Hz}, 4 \mathrm{H}, \mathrm{CH}\left(\mathrm{CH}_{3}\right)_{2}\right), 2.10\left(\mathrm{~s}, 3 \mathrm{H}, \mathrm{CH}_{3}\right), 1.24(\mathrm{~d}, J=6.7 \mathrm{~Hz}$, $\left.12 \mathrm{H}, \mathrm{CH}\left(\mathrm{CH}_{3}\right)_{2}\right)$, and $1.03\left(\mathrm{~d}, J=6.8 \mathrm{~Hz}, 12 \mathrm{H}, \mathrm{CH}\left(\mathrm{CH}_{3}\right)_{2}\right) \mathrm{ppm}$. ${ }^{13} \mathrm{C}\left\{{ }^{1} \mathrm{H}\right\}$ NMR $\left(126 \mathrm{MHz}, \mathrm{CD}_{2} \mathrm{Cl}_{2}, 298 \mathrm{~K}\right): \delta=167.5\left(\mathrm{~d}, J_{\mathrm{P}-\mathrm{C}}=\right.$ 84.5 Hz, CP); $149.6(\mathrm{NCN}) ; 146.3,139.3$, and $133.6\left(\mathrm{i}-C_{6} \mathrm{H}_{4}\right.$ and i-, $\left.m-C_{6} \mathrm{H}_{3}\right) ; 132.7\left(o-C_{6} \mathrm{H}_{4}\right) ; 131.7\left(p-C_{6} \mathrm{H}_{3}\right) ; 130.5\left(o-C_{6} \mathrm{H}_{4}\right) ; 129.5$ and $128.9\left(m-C_{6} \mathrm{H}_{4}\right) ; 126.9,125.8$, and $123.71\left(m-C_{6} \mathrm{H}_{3}\right) ; 29.7$ $\left(C\left(\mathrm{CH}_{3}\right)_{2}\right) ; 26.2$ and $23.5\left(\mathrm{C}\left(\mathrm{CH}_{3}\right)_{2}\right) ; 21.2\left(\mathrm{CH}_{3}\right)$ ppm. ${ }^{31} \mathrm{P}\left\{{ }^{1} \mathrm{H}\right\}$ NMR (202 MHz, $\left.\mathrm{CD}_{2} \mathrm{Cl}_{2}, 298 \mathrm{~K}\right): \delta=331.1\left(\mathrm{t}, J_{\mathrm{P}-\mathrm{P}}=506 \mathrm{~Hz}\right)$ and $173.6\left(\mathrm{~d}, J_{\mathrm{P}-\mathrm{P}}=506 \mathrm{~Hz}\right)$ ppm. MS (ESI, positive mode): $\mathrm{m} / \mathrm{z}=$ $571.3[4 \mathbf{b}+\mathrm{H}]^{+}$. UV-vis $\left(\lambda / \mathrm{nm} \varepsilon\left(\mathrm{M}^{-1} \mathrm{~cm}^{-1}\right)\right): 280$ (25637), 345 (36323), and 361 (36539).

\section{$\left(\mathrm{ADC}^{4-\mathrm{Tol}}\right) \mathbf{P}_{3}(\mathbf{4 c})$}

Yield: $93 \%$ (0.85 g). Single crystals suitable for X-ray diffraction were obtained by storing a saturated toluene solution of $\mathbf{4 c}$ for three days at $-24{ }^{\circ} \mathrm{C}$. Mp: $339-343{ }^{\circ} \mathrm{C}$. Elem. anal. (\%), calcd for $\mathrm{C}_{34} \mathrm{H}_{41} \mathrm{~N}_{2} \mathrm{P}_{3}$ (570.6): C, 71.56; H, 7.24; N, 4.91; found C, 71.11; H, 7.06; N, 4.65. ${ }^{1} \mathrm{H}$ NMR (500 MHz, $\left.\mathrm{CD}_{2} \mathrm{Cl}_{2}, 298 \mathrm{~K}\right): \delta=7.59(\mathrm{t}, J=$ $\left.7.8 \mathrm{~Hz}, 2 \mathrm{H}, p-\mathrm{C}_{6} H_{3}\right), 7.38\left(\mathrm{~d}, J=7.8 \mathrm{~Hz}, 4 \mathrm{H}, m-\mathrm{C}_{6} H_{3}\right), 7.05(\mathrm{~d}, J=$ $\left.8.4 \mathrm{~Hz}, 2 \mathrm{H}, \mathrm{C}_{6} H_{4}\right), 7.02\left(\mathrm{~d}, J=8.3 \mathrm{~Hz}, 2 \mathrm{H}, \mathrm{C}_{6} H_{4}\right), 2.61$ (sept, $J=$ $\left.6.8 \mathrm{~Hz}, 4 \mathrm{H}, \mathrm{CH}\left(\mathrm{CH}_{3}\right)_{2}\right), 2.23\left(\mathrm{~s}, 3 \mathrm{H}, \mathrm{CH}_{3}\right), 1.26(\mathrm{~d}, J=6.7 \mathrm{~Hz}, 12 \mathrm{H}$, $\left.\mathrm{CH}\left(\mathrm{CH}_{3}\right)_{2}\right)$, and $1.03\left(\mathrm{~d}, J=6.9 \mathrm{~Hz}, 12 \mathrm{H}, \mathrm{CH}\left(\mathrm{CH}_{3}\right)_{2}\right) \mathrm{ppm} .{ }^{13} \mathrm{C}$ $\left\{{ }^{1} \mathrm{H}\right\} \mathrm{NMR}\left(126 \mathrm{MHz}, \mathrm{CD}_{2} \mathrm{Cl}_{2}, 298 \mathrm{~K}\right): \delta=167.5\left(\mathrm{~d}, J_{\mathrm{P}-\mathrm{C}}=\right.$ 84.1 Hz, CP); $146.2(\mathrm{NCN}) ; 143.1,133.7,131.7,129.8,129.7$, 125.8, and $120.9\left(C_{6} \mathrm{H}_{3}\right.$ and $\left.C_{6} \mathrm{H}_{4}\right) ; 29.7\left(\mathrm{CH}\left(\mathrm{CH}_{3}\right)_{2}\right) ; 26.1$ and $23.5\left(\mathrm{CH}\left(\mathrm{CH}_{3}\right)_{2}\right) ; 21.7\left(\mathrm{CH}_{3}\right)$ ppm. ${ }^{31} \mathrm{P}\left\{{ }^{1} \mathrm{H}\right\}$ NMR $(202 \mathrm{MHz}$, $\left.\mathrm{CD}_{2} \mathrm{Cl}_{2}, 298 \mathrm{~K}\right): \delta=329.9\left(\mathrm{t}, J_{\mathrm{P}-\mathrm{P}}=506 \mathrm{~Hz}\right)$ and $173.6\left(\mathrm{~d}, J_{\mathrm{P}-\mathrm{P}}=\right.$ $506 \mathrm{~Hz}$ ) ppm. MS (ESI, positive mode): $m / z=571.3[4 \mathrm{c}+\mathrm{H}]^{+}$. UVvis ( $\left.\lambda / \mathrm{nm} \varepsilon\left(\mathrm{M}^{-1} \mathrm{~cm}^{-1}\right)\right): 283$ (23295), 336 (28771), 346 (29238), and 362 (29676).

\section{$\left(\mathrm{ADC}^{4-\mathrm{DMP}}\right) \mathbf{P}_{\mathbf{3}}$ (4d)}

Yield: $94 \%$ (0.93 g). Mp: $270-273{ }^{\circ} \mathrm{C}$ (decomp.). Elem. anal. (\%), calcd for $\mathrm{C}_{35} \mathrm{H}_{44} \mathrm{~N}_{3} \mathrm{P}_{3}$ (599.3): C, 70.10; H, 7.40; N, 7.01; found: $\mathrm{C}$, 69.66; H, 7.18; N 6.59. ${ }^{1} \mathrm{H}$ NMR (500 MHz, $\left.\mathrm{CD}_{2} \mathrm{Cl}_{2}, 298 \mathrm{~K}\right): \delta=$ $7.56\left(\mathrm{t}, J=7.8 \mathrm{~Hz}, 2 \mathrm{H}, p-\mathrm{C}_{6} H_{3}\right), 7.35\left(\mathrm{~d}, J=7.8 \mathrm{~Hz}, 4 \mathrm{H}, m-\mathrm{C}_{6} H_{3}\right)$, $6.90\left(\mathrm{~d}, J=9.0 \mathrm{~Hz}, 2 \mathrm{H}, \mathrm{C}_{6} H_{4}\right), 6.28\left(\mathrm{~d}, J=9.0 \mathrm{~Hz}, 2 \mathrm{H}, \mathrm{C}_{6} H_{4}\right), 2.88$ (s, 6H, N( $\left.\left.\mathrm{CH}_{3}\right)_{2}\right), 2.67$ (sept, $\left.J=6.8 \mathrm{~Hz}, 4 \mathrm{H}, \mathrm{CH}\left(\mathrm{CH}_{3}\right)_{2}\right), 1.24$ (d, $J$ $\left.=6.7 \mathrm{~Hz}, 12 \mathrm{H}, \mathrm{CH}\left(\mathrm{CH}_{3}\right)_{2}\right)$, and $0.97(\mathrm{~d}, J=6.8 \mathrm{~Hz}, 12 \mathrm{H}$, $\left.\mathrm{CH}\left(\mathrm{CH}_{3}\right)_{2}\right) \mathrm{ppm} .{ }^{13} \mathrm{C}\left\{{ }^{1} \mathrm{H}\right\} \mathrm{NMR}\left(126 \mathrm{MHz}, \mathrm{CD}_{2} \mathrm{Cl}_{2}, 298 \mathrm{~K}\right): \delta=$ $167.0\left(\mathrm{~d}, J_{\mathrm{P}-\mathrm{C}}=82.8 \mathrm{~Hz}, C \mathrm{P}\right) ; 151.9(\mathrm{NCN}) ; 146.2,138.4,134.6$, $131.4,130.8,126.3,125.8$, and $111.1\left(C_{6} \mathrm{H}_{3}\right.$ and $\left.C_{6} \mathrm{H}_{4}\right) ; 40.0$ $\left(\mathrm{N}\left(\mathrm{CH}_{3}\right)_{2}\right) ; 29.6\left(\mathrm{CH}\left(\mathrm{CH}_{3}\right)_{2}\right) ; 25.7$ and $23.5\left(\mathrm{CH}\left(\mathrm{CH}_{3}\right)_{2}\right) \mathrm{ppm} .{ }^{31} \mathrm{P}$ 
$\left\{{ }^{1} \mathrm{H}\right\} \operatorname{NMR}\left(202 \mathrm{MHz}, \mathrm{CD}_{2} \mathrm{Cl}_{2}, 298 \mathrm{~K}\right): \delta=319.5\left(\mathrm{t}, J_{\mathrm{P}-\mathrm{P}}=504 \mathrm{~Hz}\right)$ and $173.3\left(\mathrm{~d}, J_{\mathrm{P}-\mathrm{P}}=504 \mathrm{~Hz}\right) \mathrm{ppm}$. MS (ESI, positive mode): $\mathrm{m} / \mathrm{z}=$ $600.3[4 \mathrm{~d}+\mathrm{H}]^{+}$. UV-vis $\left(\lambda / \mathrm{nm}\left(\varepsilon \mathrm{M}^{-1} \mathrm{~cm}^{-1}\right)\right): 285$ (37768), 322 (46655), 343 (47543), 366 (48310), and 398 (45288).

Experimental identification of the insoluble material. A mixture of the insoluble material $(20 \mathrm{mg}, 80 \mu \mathrm{mol}$, calcd for $\left.\mathrm{Li}_{3} \mathrm{P}_{7}\right)$ and $\mathrm{IPrHCl}(80 \mathrm{mg}, 188 \mu \mathrm{mol})$ was stirred in $3 \mathrm{~mL}$ of THF for three days at $\mathrm{rt}$, resulting in a dark red suspension. A black solid was removed by filtration and the filtrate was dried in a vacuum, affording a dark red solid which was identified as $\mathrm{IPr}=\mathrm{PH}^{17}$ by NMR spectroscopy. ${ }^{1} \mathrm{H}$ NMR $\left(500 \mathrm{MHz}, \mathrm{C}_{6} \mathrm{D}_{6}, 298\right.$ $\mathrm{K}): \delta=7.23\left(\mathrm{t}, J=7.7 \mathrm{~Hz}, 2 \mathrm{H}, p-\mathrm{C}_{6} H_{3}\right), 7.14(\mathrm{~d}, J=7.6 \mathrm{~Hz}, 4 \mathrm{H}, m-$ $\left.\mathrm{C}_{6} H_{3}\right), 6.18(\mathrm{~s}, 2 \mathrm{H}, \mathrm{NCH}), 3.06$ (sept, $\left.J=6.7 \mathrm{~Hz}, 4 \mathrm{H}, \mathrm{CH}\left(\mathrm{CH}_{3}\right)_{2}\right)$, $1.92\left(\mathrm{~d}, J_{\mathrm{PH}}=165.2 \mathrm{~Hz}, 1 \mathrm{H}, \mathrm{PH}\right), 1.47(\mathrm{~d}, J=6.8 \mathrm{~Hz}, 12 \mathrm{H}$, $\left.\mathrm{CH}\left(\mathrm{CH}_{3}\right)_{2}\right)$, and $1.15\left(\mathrm{~d}, J=6.9 \mathrm{~Hz}, 12 \mathrm{H}, \mathrm{CH}\left(\mathrm{CH}_{3}\right)_{2}\right) \mathrm{ppm} .{ }^{31} \mathrm{P}$ NMR $\left(\mathrm{C}_{6} \mathrm{D}_{6}, 298 \mathrm{~K}, 500 \mathrm{MHz}\right): \delta=-134.4\left(\mathrm{~d}, J_{\mathrm{P}-\mathrm{H}}=165.2\right.$ $\mathrm{Hz})$ ppm. ${ }^{31} \mathrm{P}\left\{{ }_{1}^{1} \mathrm{H}\right\} \quad \mathrm{NMR}\left(\mathrm{C}_{6} \mathrm{D}_{6}, 298 \mathrm{~K}, 500 \mathrm{MHz}\right): \delta=$ $-134.4 \mathrm{ppm}$.

\section{Alternative synthesis of $4 \mathrm{a}$ and $4 \mathrm{c}$ from iMICs ${ }^{\mathrm{Ar}} 2 \mathrm{a}$ and $2 \mathrm{c}$}

To a $15 \mathrm{~mL}$ THF suspension of $1 \mathrm{a}(0.98 \mathrm{~g}, 1.8 \mathrm{mmol}), n$-BuLi $(2.5 \mathrm{M}, 0.8 \mathrm{~mL}, 2.0 \mathrm{mmol})$ was added at $-40{ }^{\circ} \mathrm{C}$. The resulting brown solution was stirred at $-20{ }^{\circ} \mathrm{C}$ for $45 \mathrm{~min}$ and then for $15 \mathrm{~min}$ at rt. Subsequently, $\mathrm{P}_{4}(0.3 \mathrm{~g}, 2.4 \mathrm{mmol})$ was added in one portion and the resulting reaction mixture was stirred overnight at $\mathrm{rt}$. The volatiles were removed under vacuum to obtain a dark residue, which was extracted with toluene $(3 \times 10$ $\mathrm{mL})$. The filtrate was dried in a vacuum to obtain $4 \mathrm{a}$. Yield: $41 \%$ (0.4 g).

$\left(\mathrm{ADC}^{\mathbf{4}-\mathrm{Tol}}\right) \mathbf{P}_{\mathbf{3}}$ (4c). Similarly, treatment of $3 \mathbf{c}$ with $\mathrm{P}_{4}$ gave $\mathbf{4 c}$. Yield: $36 \%(0.4 \mathrm{~g})$.

\section{Syntheses of complexes $5 a, 5 b, 6$, and 7}

$\left[\left(\mathbf{A D C}^{\mathbf{P h}}\right) \mathbf{P}_{3}\right] \mathbf{F e}(\mathbf{C O})_{4}$ (5a). To a mixture of $4 \mathbf{4 a}(651 \mathrm{mg}, 1.2$ $\mathrm{mmol})$ and $\mathrm{Fe}_{2}(\mathrm{CO})_{9}(510 \mathrm{mg}, 1.4 \mathrm{mmol}), 30 \mathrm{~mL}$ THF was added at rt. The brown colored solution changed to a dark red colored solution after $15 \mathrm{~min}$, which was further stirred overnight. The volatiles were removed in a vacuum to afford a red solid, which was extracted with $30 \mathrm{~mL}$ toluene. The volume of the filtrate was reduced to $10 \mathrm{~mL}$ and stored at $-30^{\circ}$ for one week to obtained orange needles of $5 \mathbf{a}(696 \mathrm{mg}, 80 \%)$, which were also suitable for X-ray diffraction. Mp: $167-172{ }^{\circ} \mathrm{C}$ (decomp.). Elem. anal. (\%), calcd for $\mathrm{C}_{37} \mathrm{H}_{39} \mathrm{FeN}_{2} \mathrm{O}_{4} \mathrm{P}_{3}$ (724.5): C, 61.34; $\mathrm{H}, 5.43 ; \mathrm{N}, 3.87$; found: C, 59.66; H, 5.24; N, 3.71. ${ }^{1} \mathrm{H}$ NMR $\left(500 \mathrm{MHz}, \mathrm{CD}_{2} \mathrm{Cl}_{2}, 298\right.$ $\mathrm{K}): \delta=7.60\left(\mathrm{t}, J=7.8 \mathrm{~Hz}, 2 \mathrm{H}, p-\mathrm{C}_{6} H_{3}\right), 7.38(\mathrm{~d}, J=7.8 \mathrm{~Hz}, 4 \mathrm{H}, m-$ $\left.\mathrm{C}_{6} H_{3}\right), 7.34$ (t, $\left.J=7.5 \mathrm{~Hz}, 1 \mathrm{H}, p-\mathrm{C}_{6} H_{5}\right), 7.22-7.15(\mathrm{~m}, 4 \mathrm{H}, o-, m-$ $\left.\mathrm{C}_{6} H_{5}\right), 2.57$ (sept, $\left.J=6.7 \mathrm{~Hz}, 4 \mathrm{H}, \mathrm{CH}\left(\mathrm{CH}_{3}\right)_{2}\right), 1.27(\mathrm{~d}, J=6.7 \mathrm{~Hz}$, $\left.12 \mathrm{H}, \mathrm{CH}\left(\mathrm{CH}_{3}\right)_{2}\right)$, and $1.01\left(\mathrm{~d}, J=6.8 \mathrm{~Hz}, 12 \mathrm{H}, \mathrm{CH}\left(\mathrm{CH}_{3}\right)_{2}\right) \mathrm{ppm}$. ${ }^{13} \mathrm{C}\left\{{ }^{1} \mathrm{H}\right\}$ NMR (126 MHz, $\left.\mathrm{CD}_{2} \mathrm{Cl}_{2}, 298 \mathrm{~K}\right): \delta=215.1(\mathrm{CO}) ; 161.7(\mathrm{~d}$, $\left.J_{\mathrm{P}-\mathrm{C}}=70.3 \mathrm{~Hz}, C \mathrm{P}\right) ; 146.0(\mathrm{NCN}), 133.1,132.2,129.7,129.5$, 129.3, 128.7, 126.1, and $123.1\left(C_{6} \mathrm{H}_{3}\right.$ and $\left.C_{6} \mathrm{H}_{5}\right) ; 29.8\left(\mathrm{CH}\left(\mathrm{CH}_{3}\right)_{2}\right)$; 26.0 and $23.5\left(\mathrm{CH}\left(\mathrm{CH}_{3}\right)_{2}\right) \mathrm{ppm} .{ }^{31} \mathrm{P}\left\{{ }^{1} \mathrm{H}\right\}$ NMR $\left(202 \mathrm{MHz}, \mathrm{CD}_{2} \mathrm{Cl}_{2}\right.$, $298 \mathrm{~K}): \delta=316.8\left(\mathrm{t}, J_{\mathrm{P}-\mathrm{P}}=531 \mathrm{~Hz}\right)$ and $145.4\left(\mathrm{~d}, J_{\mathrm{P}-\mathrm{P}}=531\right.$ $\mathrm{Hz})$ ppm. MS (ESI, positive mode): $m / z=725.1[5 \mathbf{a}+\mathbf{H}]^{+}$. UV-vis $\left(\lambda / \mathrm{nm} \varepsilon\left(\mathrm{M}^{-1} \mathrm{~cm}^{-1}\right)\right): 285$ (33061), 328 (31345), and 428 (37184). IR (ATR, diamond): $\tilde{v} / \mathrm{cm}^{-1}=2041,1966,1937$, and 1919.
$\left[\left(\mathrm{ADC}^{3-\mathrm{Tol}}\right) \mathbf{P}_{3}\right] \mathbf{F e}(\mathbf{C O})_{4}$ (5b). Compound $5 \mathbf{b}$ was synthesized following a similar procedure to that described above for $\mathbf{5 a}$ using $4 \mathbf{b}(300 \mathrm{mg}, 0.53 \mathrm{mmol})$ and $\mathrm{Fe}_{2}(\mathrm{CO})_{9}(191 \mathrm{mg}, 0.53$ $\mathrm{mmol}$ ) as an orange crystalline solid. Yield: $84 \%$ (333 $\mathrm{mg})$. Crystals suitable for X-ray diffraction were obtained by storing a saturated toluene solution of $\mathbf{5 b}$ overnight at rt. Mp: 180$182{ }^{\circ} \mathrm{C}$ (decomp.) Elem. anal. (\%), calcd for $5 \mathrm{~b}, \mathrm{C}_{38} \mathrm{H}_{41} \mathrm{FeN}_{2} \mathrm{O}_{4} \mathrm{P}_{3}$ (738.5): C, 61.80; H, 7.56; N, 3.79; found C, 62.69; H, 5.95; N, 3.45. ${ }^{1} \mathrm{H}$ NMR $\left(500 \mathrm{MHz}, \mathrm{CD}_{2} \mathrm{Cl}_{2}, 298 \mathrm{~K}\right): \delta=7.59(\mathrm{t}, J=7.8 \mathrm{~Hz}$, $\left.2 \mathrm{H}, p-\mathrm{C}_{6} H_{3}\right), 7.37\left(\mathrm{~d}, J=7.8 \mathrm{~Hz}, 4 \mathrm{H}, m-\mathrm{C}_{6} H_{3}\right), 7.15(\mathrm{~d}, J=7.4 \mathrm{~Hz}$, $\left.1 \mathrm{H}, o-\mathrm{C}_{6} H_{4}\right), 7.08\left(\mathrm{t}, J=7.7 \mathrm{~Hz}, 1 \mathrm{H}, m-\mathrm{C}_{6} H_{4}\right), 7.00\left(\mathrm{~s}, 1 \mathrm{H}, o-\mathrm{C}_{6} H_{4}\right)$, $6.94\left(\mathrm{~d}, J=7.7 \mathrm{~Hz}, 1 \mathrm{H}, p-\mathrm{C}_{6} H_{4}\right), 2.56$ (sept, $J=6.6 \mathrm{~Hz}, 4 \mathrm{H}$, $\left.\mathrm{CH}\left(\mathrm{CH}_{3}\right)_{2}\right), 2.09\left(\mathrm{~s}, 3 \mathrm{H}, \mathrm{CH}_{3}\right), 1.27\left(\mathrm{~d}, J=6.6 \mathrm{~Hz}, 12 \mathrm{H}, \mathrm{CH}\left(\mathrm{CH}_{3}\right)_{2}\right)$, and $1.04\left(\mathrm{~d}, J=6.7 \mathrm{~Hz}, 12 \mathrm{H}, \mathrm{CH}\left(\mathrm{CH}_{3}\right)_{2}\right) \mathrm{ppm} .{ }^{13} \mathrm{C}\left\{{ }^{1} \mathrm{H}\right\} \mathrm{NMR}(126$ $\left.\mathrm{MHz}, \mathrm{CD}_{2} \mathrm{Cl}_{2}, 298 \mathrm{~K}\right): \delta=215.1$ and $214.9(C \mathrm{O}) ; 161.6\left(\mathrm{~d}, J_{\mathrm{P}-\mathrm{C}}=\right.$ $71 \mathrm{~Hz}, \mathrm{NCP}) ; 147.6(\mathrm{NCN}) ; 146.1,139.5,133.1,133.0,132.1$, 130.3, 129.9, 129.0, 126.8, 126.0, and $122.9\left(C_{6} \mathrm{H}_{3}\right.$ and $\left.C_{6} \mathrm{H}_{5}\right)$; $29.8\left(\mathrm{CH}\left(\mathrm{CH}_{3}\right)_{2}\right) ; 26.1$ and $23.6\left(\mathrm{CH}\left(\mathrm{CH}_{3}\right)_{2}\right) ; 21.2\left(\mathrm{CH}_{3}\right) \mathrm{ppm} .{ }^{31} \mathrm{P}$ $\left\{{ }^{1} \mathrm{H}\right\}$ NMR $\left(202 \mathrm{MHz}, \mathrm{CD}_{2} \mathrm{Cl}_{2}, 298 \mathrm{~K}\right): \delta=315.5\left(\mathrm{t}, J_{\mathrm{P}-\mathrm{P}}=531 \mathrm{~Hz}\right)$ and $145.4\left(\mathrm{~d}, J_{\mathrm{P}-\mathrm{P}}=532 \mathrm{~Hz}\right) \mathrm{ppm}$. MS (ESI, positive mode): $\mathrm{m} / \mathrm{z}=$ $739.1[5 \mathbf{b}+\mathrm{H}]^{+}$. UV-vis $\left(\lambda / \mathrm{nm} \varepsilon\left(\mathrm{M}^{-1} \mathrm{~cm}^{-1}\right)\right): 282$ (35189), 327 (29758), and 416 (37568). IR (ATR, diamond): $\tilde{v} / \mathrm{cm}^{-1}=2039$, 2007, 1962, and 1921.

$\left[\left(\mathbf{A D C}^{\mathbf{P h}}\right) \mathbf{P}_{3}\right] \mathbf{M o}(\mathbf{C O})_{5}(6)$. To a mixture of $4 a(447 \mathrm{mg}, 0.8$ $\mathrm{mmol})$ and $\mathrm{Mo}(\mathrm{CO})_{6}(212 \mathrm{mg}, 0.8 \mathrm{mmol}), 20 \mathrm{~mL}$ THF was added at rt. The yellow suspension was stirred for three days at $60{ }^{\circ} \mathrm{C}$. Filtration through a plug of Celite afforded an orange solution. The volatiles were removed under vacuum to obtain 6 as a yellow solid (523 mg, 81\%). Crystals suitable for X-ray diffraction were obtained by a slow diffusion of $n$-hexane into a saturated toluene solution of $\mathbf{6}$. Elem. anal. (\%), calcd for $\mathbf{6}$, $\mathrm{C}_{38} \mathrm{H}_{39} \mathrm{MoN}_{2} \mathrm{O}_{5} \mathrm{P}_{3}$ (792.6): C, 57.58; H, 4.96; N, 3.53; found: C, 57.06; $\mathrm{H}, 4.73 ; \mathrm{N}, 3.25 .{ }^{1} \mathrm{H}$ NMR (500 MHz, $\left.\mathrm{CD}_{2} \mathrm{Cl}_{2}, 298 \mathrm{~K}\right): \delta=$ $7.60\left(\mathrm{t}, J=7.8 \mathrm{~Hz}, 2 \mathrm{H}, p-\mathrm{C}_{6} H_{3}\right), 7.38\left(\mathrm{~d}, J=7.8 \mathrm{~Hz}, 4 \mathrm{H}, m-\mathrm{C}_{6} H_{3}\right)$, $7.35\left(\mathrm{t}, J=7.6 \mathrm{~Hz}, 1 \mathrm{H}, p-\mathrm{C}_{6} H_{5}\right), 7.21\left(\mathrm{t}, J=7.8 \mathrm{~Hz}, 2 \mathrm{H}, m-\mathrm{C}_{6} H_{5}\right)$, 7.17 (d, $J=7.9 \mathrm{~Hz}, 2 \mathrm{H}, o-\mathrm{C}_{6} H_{5}$ ), 2.58 (sept, $J=6.7 \mathrm{~Hz}, 4 \mathrm{H}$, $\left.\mathrm{CH}\left(\mathrm{CH}_{3}\right)_{2}\right), 1.27\left(\mathrm{~d}, J=6.7 \mathrm{~Hz}, 12 \mathrm{H}, \mathrm{CH}\left(\mathrm{CH}_{3}\right)_{2}\right)$, and $1.02(\mathrm{~d}, J=$ $\left.6.8 \mathrm{~Hz}, 12 \mathrm{H}, \mathrm{CH}\left(\mathrm{CH}_{3}\right)_{2}\right) .{ }^{13} \mathrm{C}\left\{{ }^{1} \mathrm{H}\right\} \mathrm{NMR}\left(126 \mathrm{MHz}, \mathrm{CD}_{2} \mathrm{Cl}_{2}, 298 \mathrm{~K}\right)$ : $\delta=206.0$ and $201.8(C O) ; 164.4\left(\mathrm{~d}, J_{\mathrm{P}-\mathrm{C}}=73 \mathrm{~Hz}, \mathrm{NCP}\right) ; 146.1$ $(\mathrm{NCN}) ; 133.2,132.2,132.1,129.7,129.2$, and $126.1\left(C_{6} \mathrm{H}_{3}\right.$ and $\left.\mathrm{C}_{6} \mathrm{H}_{5}\right) ; 29.8\left(\mathrm{CH}\left(\mathrm{CH}_{3}\right)_{2}\right) ; 26.0$ and $23.6\left(\mathrm{CH}\left(\mathrm{CH}_{3}\right)_{2}\right) \mathrm{ppm} .{ }^{31} \mathrm{P}\left\{{ }^{1} \mathrm{H}\right\}$ $\operatorname{NMR}\left(202 \mathrm{MHz}, \mathrm{CD}_{2} \mathrm{Cl}_{2}, 298 \mathrm{~K}\right): \delta=299.1\left(\mathrm{t}, J_{\mathrm{P}-\mathrm{P}}=510 \mathrm{~Hz}\right)$ and $160.2\left(\mathrm{~d}, J_{\mathrm{P}-\mathrm{P}}=511 \mathrm{~Hz}\right) \mathrm{ppm}$. IR (ATR, diamond): $\tilde{v} / \mathrm{cm}^{-1}=$ 2065, 2051, 1945, 1925, and 1911.

$\left[\left(\mathbf{A D C}^{4-\mathrm{DMP}}\right) \mathbf{P}_{3}\right] \mathbf{W}(\mathbf{C O})_{5}$ (7). A $10 \mathrm{~mL}$ THF solution of W(CO) $)_{6}$ (212 $\mathrm{mg}, 0.8 \mathrm{mmol}$ ) was irradiated under UV light for $3 \mathrm{~h}$ and then combined with a $6 \mathrm{~mL}$ THF solution of $4 \mathbf{d}(447 \mathrm{mg}, 0.8$ $\mathrm{mmol}$ ). The yellow solution was stirred overnight at rt. The volatiles were removed under vacuum to obtain 7 as a yellow solid (256 mg, 88\%). Crystals suitable for X-ray diffraction were obtained by slow evaporation of a saturated toluene solution of 7 at rt. Elem. anal. (\%), calcd for 7, $\mathrm{C}_{40} \mathrm{H}_{44} \mathrm{~N}_{3} \mathrm{O}_{5} \mathrm{P}_{3} \mathrm{~W}$ (923.6): C, $52.02 ; \mathrm{H}, 4.80 ; \mathrm{N}, 4.55$; found $\mathrm{C}, 51.40 ; \mathrm{H}, 4.39 ; \mathrm{N}, 4.10 .{ }^{1} \mathrm{H}$ NMR $\left(500 \mathrm{MHz}, \mathrm{CD}_{2} \mathrm{Cl}_{2}, 298 \mathrm{~K}\right): \delta=7.61\left(\mathrm{t}, J=7.8 \mathrm{~Hz}, 2 \mathrm{H}, p-\mathrm{C}_{6} H_{3}\right)$, $7.41\left(\mathrm{~d}, J=7.8 \mathrm{~Hz}, 4 \mathrm{H}, m-\mathrm{C}_{6} H_{3}\right), 6.91\left(\mathrm{~d}, J=9.2 \mathrm{~Hz}, 2 \mathrm{H}, \mathrm{C}_{6} H_{4}\right)$, $6.33\left(\mathrm{~d}, J=9.2 \mathrm{~Hz}, 2 \mathrm{H}, \mathrm{C}_{6} H_{4}\right), 2.88\left(\mathrm{~s}, 6 \mathrm{H}, \mathrm{N}\left(\mathrm{CH}_{3}\right)_{2}\right), 2.60$ (sept, $J$ 
$\left.=6.8 \mathrm{~Hz}, 4 \mathrm{H}, \mathrm{CH}\left(\mathrm{CH}_{3}\right)_{2}\right), 1.26\left(\mathrm{~d}, J=6.9 \mathrm{~Hz}, 12 \mathrm{H}, \mathrm{CH}\left(\mathrm{CH}_{3}\right)_{2}\right)$, and $1.00\left(\mathrm{~d}, J=6.8 \mathrm{~Hz}, 12 \mathrm{H}, \mathrm{CH}\left(\mathrm{CH}_{3}\right)_{2}\right) \mathrm{ppm} .{ }^{13} \mathrm{C}\left\{{ }^{1} \mathrm{H}\right\} \mathrm{NMR}(126$ $\left.\mathrm{MHz}, \mathrm{CD}_{2} \mathrm{Cl}_{2}, 298 \mathrm{~K}\right): \delta=197.3$ and 192.0 (CO); 152.1 (NCP); $146.1(\mathrm{NCN}) ; 134.3,131.8,130.7,129.9,126.1,111.2$, and 108.7 $\left(C_{6} \mathrm{H}_{3}\right.$ and $\left.C_{6} \mathrm{H}_{5}\right) ; 40.0\left(\mathrm{~N}\left(\mathrm{CH}_{3}\right)_{2}\right) ; 29.7\left(\mathrm{CH}\left(\mathrm{CH}_{3}\right)_{2}\right) ; 25.6$ and 23.6 $\left(\mathrm{CH}\left(\mathrm{CH}_{3}\right)_{2}\right)$ ppm. ${ }^{31} \mathrm{P}\left\{{ }^{1} \mathrm{H}\right\}$ NMR $\left(202 \mathrm{MHz}, \mathrm{CD}_{2} \mathrm{Cl}_{2}, 298 \mathrm{~K}\right): \delta=$ $250.9\left(\mathrm{t}, J_{\mathrm{P}-\mathrm{P}}=512 \mathrm{~Hz}\right.$, with ${ }^{183} \mathrm{~W}$ satellites, $\left.J_{\mathrm{W}-\mathrm{P}}=202 \mathrm{~Hz}\right)$ and $157.0\left(\mathrm{~d}, J_{\mathrm{P}-\mathrm{P}}=505 \mathrm{~Hz}\right.$ ) ppm. MS (ESI): $m / z=924.2[7+\mathrm{H}]^{+}$. IR (ATR, diamond): $\tilde{v} / \mathrm{cm}^{-1}=2063,1978,1925$, and 1907.

\section{Conclusions}

In conclusion, the direct functionalization of white phosphorus $\left(\mathrm{P}_{4}\right)$ with anionic dicarbenes (ADCs) (2a-2d) as well as with mesoionic carbenes (iMICs ${ }^{\mathrm{Ar}}$ ) (3a and $\mathbf{3 c}$ ) that leads to the formation of unique 1,2,3-triphosphol-2-ide derivatives $4 a-4 d$ as crystalline solids up to $98 \%$ yield has been reported. The isolation of $\mathrm{C}_{2} \mathrm{P}_{3}$-heterocycles $\mathbf{4 a}-\mathbf{4 d}$ is unprecedented in the $\mathrm{P}_{4}$ activation by singlet carbenes and main-group compounds. The formation of $\mathbf{4 a - 4 d}$ suggests unique $[3+1]$ fragmentation of $\mathrm{P}_{4}$ into $\mathrm{P}_{3}{ }^{+}$and $\mathrm{P}^{-}$. The former species combines with an ADC to give $4 a-4 d$, whereas the latter reacts with additional $\mathrm{P}_{4}$ to form $\left(\mathrm{P}_{7}\right)^{3-}$ that can be isolated as $\mathrm{Li}_{3} \mathrm{P}_{7}$. Electronic structures of $4 \mathbf{a}-$ 4d have been analyzed by computational studies, which, along with the crystallographic data, show that both $\mathrm{C}_{3} \mathrm{~N}_{2}$ - and $\mathrm{C}_{2} \mathrm{P}_{3}$ rings of $\mathbf{4 a - 4 d}$ are $6 \pi$-electron aromatic systems. Thus, $\mathbf{4 a - 4 d}$ can be considered as neutral analogues of cyclopentadienyl anions. The $\mathrm{C}_{2} \mathrm{P}_{3}$-ring of $\mathbf{4 a - 4 d}$ is negatively polarized towards the central phosphorus atom, and hence $\mathbf{4 a - 4 d}$ may also function as potent two-electron $\sigma$-donor ligands. This feature has been demonstrated with the isolation of transition metal complexes 5a, 5b, 6, and 7. Consequently, 4a-4d have interesting perspectives as ligands in main-group element as well as transition-metal chemistry and catalysis. Further investigations in this direction are currently underway in this laboratory.

\section{Conflicts of interest}

There are no conflicts to declare.

\section{Acknowledgements}

We gratefully acknowledge the support from the Deutsche Forschungsgemeinschaft (DFG) and thank Professor Norbert W. Mitzel for his continuous support. The authors gratefully acknowledge the support by computing time provided by the Paderborn Center for Parallel Computing (PC2).

\section{References}

1 D. E. C. Corbridge, Phosphorus: Chemistry, Biochemistry and Technology, CRC Press, 6th edn, 2016.

2 J. M. Lynam, Angew. Chem., Int. Ed., 2008, 47, 831-833.

3 (a) B. M. Cossairt, N. A. Piro and C. C. Cummins, Chem. Rev., 2010, 110, 4164-4177; (b) M. Caporali, L. Gonsalvi, A. Rossin and M. Peruzzini, Chem. Rev., 2010, 110, 4178-4235; (c) M. Peruzzini, L. Gonsalvi and A. Romerosa, Chem. Soc.
Rev., 2005, 34, 1038-1047; (d) C. C. Cummins, Angew. Chem., Int. Ed., 2006, 45, 862-870.

4 (a) M. Scheer, G. Balázs and A. Seitz, Chem. Rev., 2010, 110, 4236-4256; (b) S. Khan, S. S. Sen and H. W. Roesky, Chem. Commun., 2012, 48, 2169-2179; (c) N. A. Giffin and J. D. Masuda, Coord. Chem. Rev., 2011, 255, 1342-1359; (d) M. H. Holthausen and J. J. Weigand, Chem. Soc. Rev., 2014, 43, 6639-6657.

5 (a) S. Heinl, S. Reisinger, C. Schwarzmaier, M. Bodensteiner and M. Scheer, Angew. Chem., Int. Ed., 2014, 53, 7639-7642; (b) W. W. Seidel, O. T. Summerscales, B. O. Patrick and M. D. Fryzuk, Angew. Chem., Int. Ed., 2009, 48, 115-117; (c) B. M. Cossairt and C. C. Cummins, Angew. Chem., Int. Ed., 2008, 47, 169-172; (d) B. M. Cossairt and C. C. Cummins, Angew. Chem., Int. Ed., 2008, 47, 8863-8866; (e) N. A. Piro and C. C. Cummins, J. Am. Chem. Soc., 2008, 130, 95249535; $(f)$ A. R. Fox, C. R. Clough, N. A. Piro and C. C. Cummins, Angew. Chem., Int. Ed., 2007, 46, 973-976; (g) N. A. Piro, J. S. Figueroa, J. T. McKellar and C. C. Cummins, Science, 2006, 313, 1276-1279; (h) B. M. Cossairt, M.-C. Diawara and C. C. Cummins, Science, 2009, 323, 602; (i) S. Du, J. Yin, Y. Chi, L. Xu and W.-X. Zhang, Angew. Chem., Int. Ed., 2017, 56, 15886-15890; (j) C. Schwarzmaier, A. Noor, G. Glatz, M. Zabel, A. Y. Timoshkin, B. M. Cossairt, C. C. Cummins, R. Kempe and M. Scheer, Angew. Chem., Int. Ed., 2011, 50, 7283-7286; (k) C. Camp, L. Maron, R. G. Bergman and J. Arnold, J. Am. Chem. Soc., 2014, 136, 17652-17661; (l) S. Pelties, D. Herrmann, B. de Bruin, F. Hartl and R. Wolf, Chem. Commun., 2014, 50, 7014-7016; $(m)$ S. L. Yao, N. Lindenmaier, Y. Xiong, S. Inoue, T. Szilvasi, M. Adelhardt, J. Sutter, K. Meyer and M. Driess, Angew. Chem., Int. Ed., 2015, 54, 1250-1254; (n) F. Dielmann, A. Timoshkin, M. Piesch, G. Balázs and M. Scheer, Angew. Chem., Int. Ed., 2017, 56, 1671-1675; (o) F. Spitzer, C. Graßl, G. Balázs, E. M. Zolnhofer, K. Meyer and M. Scheer, Angew. Chem., Int. Ed., 2016, 55, 4340-4344; (p) F. Spitzer, C. Graßl, G. Balázs, E. Mädl, M. Keilwerth, E. M. Zolnhofer, K. Meyer and M. Scheer, Chem.-Eur. J., 2017, 23, 2716-2721; (q) B. L. Tran, M. Singhal, H. Park, O. P. Lam, M. Pink, J. Krzystek, A. Ozarowski, J. Telser, K. Meyer and D. J. Mindiola, Angew. Chem., Int. Ed., 2010, 49, 9871-9875; (r) J. E. Borger, M. S. Bakker, A. W. Ehlers, M. Lutz, J. Chris Slootweg and K. Lammertsma, Chem. Commun., 2016, 52, 3284-3287.

6 (a) S. Khan, R. Michel, J. M. Dieterich, R. A. Mata, H. W. Roesky, J.-P. Demers, A. Lange and D. Stalke, J. Am. Chem. Soc., 2011, 133, 17889-17894; (b) J. W. Dube, C. M. E. Graham, C. L. B. Macdonald, Z. D. Brown, P. P. Power and P. J. Ragogna, Chem.-Eur. J., 2014, 20, 6739-6744; (c) R. J. Schwamm, M. Lein, M. P. Coles and C. M. Fitchett, Angew. Chem., Int. Ed., 2016, 55, 1479814801; (d) M. Arrowsmith, M. S. Hill, A. L. Johnson, G. Kociok-Köhn and M. F. Mahon, Angew. Chem., Int. Ed., 2015, 54, 7882-7885; (e) K. X. Bhattacharyya, S. Dreyfuss, N. Saffon-Merceron and N. Mézailles, Chem. Commun., 2016, 52, 5179-5182; (f) S. Khan, R. Michel, S. S. Sen, 
H. W. Roesky and D. Stalke, Angew. Chem., Int. Ed., 2011, 50, 11786-11789; (g) W. Lu, K. Xu, Y. Li, H. Hirao and R. Kinjo, Angew. Chem., Int. Ed., 2018, 57, 15691-15695; (h) D. Holschumacher, T. Bannenberg, K. Ibrom, C. G. Daniliuc, P. G. Jones and M. Tamm, Dalton Trans., 2010, 39, 10590-10592; (i) J. E. Borger, A. W. Ehlers, M. Lutz, J. C. Slootweg and K. Lammertsma, Angew. Chem., Int. Ed., 2014, 53, 12836-12839.

7 (a) O. Back, G. Kuchenbeiser, B. Donnadieu and G. Bertrand, Angew. Chem., Int. Ed., 2009, 48, 5530-5533; (b) J. D. Masuda, W. W. Schoeller, B. Donnadieu and G. Bertrand, Angew. Chem., Int. Ed., 2007, 46, 7052-7055; (c) C. D. Martin, C. M. Weinstein, C. E. Moore, A. L. Rheingold and G. Bertrand, Chem. Commun., 2013, 49, 4486-4488; (d) C. L. Dorsey, B. M. Squires and T. W. Hudnall, Angew. Chem., Int. Ed., 2013, 52, 4462-4465; (e) J. D. Masuda, W. W. Schoeller, B. Donnadieu and G. Bertrand, J. Am. Chem. Soc., 2007, 129, 14180-14181.

8 (a) J. E. Borger, A. W. Ehlers, J. C. Slootweg and K. Lammertsma, Chem.-Eur. J., 2017, 23, 11738-11746; (b) D. Tofan and C. C. Cummins, Angew. Chem., Int. Ed., 2010, 49, 7516-7518.

9 (a) Y. Wang, Y. Xie, P. Wei, R. B. King, H. F. Schaefer III, P. v. R. Schleyer and G. H. Robinson, J. Am. Chem. Soc., 2008, 130, 14970-14971; (b) M. H. Holthausen, S. K. Surmiak, P. Jerabek, G. Frenking and J. J. Weigand, Angew. Chem., Int. Ed., 2013, 52, 11078-11082.

10 (a) D. W. Stephan, Science, 2016, 354, aaf7229; (b) D. W. Stephan and G. Erker, Angew. Chem., Int. Ed., 2015, 54, 6400-6441; (c) D. W. Stephan, Acc. Chem. Res., 2015, 48, 306-316.

11 (a) E. Aldeco-Perez, A. J. Rosenthal, B. Donnadieu, P. Parameswaran, G. Frenking and G. Bertrand, Science, 2009, 326, 556-559; (b) D. J. Nelson and S. P. Nolan, Chem. Soc. Rev., 2013, 42, 6723-6753; (c) G. Ung and G. Bertrand, Chem.-Eur. J., 2011, 17, 8269-8272; (d) G. Guisado-Barrios, J. Bouffard, B. Donnadieu and G. Bertrand, Angew. Chem., Int. Ed., 2010, 49, 4759-4762; (e) A. Vivancos, C. Segarra and M. Albrecht, Chem. Rev., 2018, 118, 9493-9586.
12 D. Rottschäfer, F. Ebeler, T. Strothmann, B. Neumann, H.-G. Stammler, A. Mix and R. S. Ghadwal, Chem.-Eur. J., 2018, 24, 3716-3720.

13 (a) N. K. T. Ho, B. Neumann, H.-G. Stammler, V. H. Menezes da Silva, D. G. Watanabe, A. A. C. Braga and R. S. Ghadwal, Dalton Trans., 2017, 46, 12027-12031; (b) R. S. Ghadwal, S. O. Reichmann and R. Herbst-Irmer, Chem.-Eur. J., 2015, 21, 4247-4251.

14 (a) S. Du, J. Yang, J. Hu, Z. Chai, G. Luo, Y. Luo, W. X. Zhang and Z. Xi, J. Am. Chem. Soc., 2019, 141, 6843-6847; (b) L. Xu, Y. Chi, S. Du, W.-X. Zhang and Z. Xi, Angew. Chem., Int. Ed., 2016, 55, 9187-9190.

15 M. Baudler and K. Glinka, Chem. Rev., 1993, 93, 1623-1667. 16 M. Baudler, Angew. Chem., Int. Ed., 1987, 26, 419-441.

17 M. Cicač-Hudi, J. Bender, S. H. Schlindwein, M. Bispinghoff, M. Nieger, H. Grützmacher and D. Gudat, Eur. J. Inorg. Chem., 2016, 2016, 649-658.

18 (a) C. L. Boulangé, in Encyclopedia of Analytical Science (Third Edition), ed. P. Worsfold, C. Poole, A. Townshend and M.Miró, Academic Press, Oxford, 2019, pp. 319-327; (b) O. Kühl, Phosphorus-31 NMR Spectroscopy, Springer-Verlag Berlin Heidelberg, 2008.

19 CCDC 1939608-1939615 contain the supplementary crystallographic data for this paper. $\dagger$

20 P. Pyykkö and M. Atsumi, Chem.-Eur. J., 2009, 15, 1277012779.

21 (a) R. S. P. Turbervill, A. R. Jupp, P. S. B. McCullough, D. Ergöçmen and J. M. Goicoechea, Organometallics, 2013, 32, 2234-2244; (b) R. S. P. Turbervill and J. M. Goicoechea, Chem. Commun., 2012, 48, 6100-6102.

22 P. v. R. Schleyer, C. Maerker, A. Dransfeld, H. Jiao and N. J. R. van Eikema Hommes, J. Am. Chem. Soc., 1996, 118, 6317-6318.

23 D. Geuenich, K. Hess, F. Köhler and R. Herges, Chem. Rev., 2005, 105, 3758-3772.

24 E. P. Kyba, K. L. Hassett, B. Sheikh, J. S. McKennis, R. B. King and R. E. Davis, Organometallics, 1985, 4, 994-1001. 